\title{
Establishment of significant improvement of hearing post-surgery for mucosal type of chronic suppurative otitis media
}

\section{Deepthy Das, Gurumani Sriraman*, Valli Rajasekaran} Department of ENT, Shri Sathya Sai Medical College and Research Institute, Ammapettai, Kanchipuram district,
Tamil Nadu, India

Received: 09 February 2020

Revised: 01 April 2020

Accepted: 02 April 2020

\author{
*Correspondence: \\ Dr. Gurumani Sriraman, \\ E-mail: ent@sssmcri.ac.in
}

Copyright: () the author(s), publisher and licensee Medip Academy. This is an open-access article distributed under the terms of the Creative Commons Attribution Non-Commercial License, which permits unrestricted non-commercial use, distribution, and reproduction in any medium, provided the original work is properly cited.

\begin{abstract}
Chronic suppurative otitis media occurs in the population as a common disease among people living in low socioeconomic status. The associated complaints such as hearing difficulty, irritation, discharge makes it difficult for the people to carry out their daily activities. Therefore, their immediate need for treatment occurs. This review aims at analysing the post-operative outcome of hearing following tympanoplasty in order to overcome their morbidity. The source of this study has been obtained from Pubmed, Google scholar and EMBASE. The material for this review was selected from a reference published between January 1975 to December 2014, with this analysis was made. The preop ABG in the studies were all falling in mild to moderate hearing loss according to WHO classification of hearing loss. The patients were grouped in Austin-Kartush criteria, groups A to E. The Austin-Kartush classification group A had 3 studies included. The mean ABG for each were 11.5,8.3 and 13.5. In group B,3studies were included. The mean ABG for each were 11.9,10.9 and 11.1. Group $C$ had 4 studies. The mean ABG were 17.7,15,17.1 and 15.7. Group D had 4 studies included which had the same mean ABG 16.6. Group E had just 1 study of mean ABG 20.1. This review helped to establish that there was significant improvement in hearing post-surgery, in patients with varying degrees of hearing loss.
\end{abstract}

Keywords: Otitis media, Tympanoplasty, Hearing tests, Ear ossicles

\section{INTRODUCTION}

Chronic suppurative otitis media affecting the patients have main complaints include hearing difficulty, ear pain, discharge and intra-cranial and extra cranial complications. In order to overcome their morbidity to carry out daily activities, patients opt for surgery. This review aims at analysing the post-operative outcome of hearing following tympanoplasty.

The outcome of surgery is based on many factors including age/sex, socio-economic status, chronicity of the disease and pre-operative ABG. Type I when 1 ossicle is involved. Type II when any 2 ossicles are involved. Type III when footplate of stapes only present. Type IV when an eroded footplate present. Type V Tympanoplasty refers to a fenestration created in the horizontal semi-circular canal. ${ }^{1-3}$ Pure tone audiometry done pre- and post-operatively to assess the ossicular status and the degree of hearing loss helps to plan the patient's further treatment and provide improvement for their morbidity. ${ }^{4.5}$

\section{METHODS}

The articles for this review have been obtained from over ten years between 1975 to 2014. Sources were obtained from EMBASE, Google scholar and Pubmed. The studies 
were divided on the type of tympanoplasty done, i.e. Group A to E. The characteristics used to obtain the result were just based on factors such as age, pre-op hearing status and post-operative hearing improvement. This was based on ABG data obtained.

\section{Age}

From the data obtained it was found that in all studies the minimum age was not less than 10 years i.e. paediatric age group was part of their work. 5 studies had included patients above 70 years of age. 2 studies had patients only upto the age group of 60 years. Other studies had not mentioned the age group addressing them as not relevant.

\section{Surgery done and follow up}

Two studies had undergone tympanoplasty with mastoidectomy with only one study having data of follow-up for 6 months. 2 studies had undergone tympanoplasty with ossicular reconstruction both having a follow-up period of 50 months. 3 studies underwent canal wall down surgery in which 2 studies had a follow up of 1 year and 1 study had a follow up of 36 months.

\section{Hearing status before surgery}

In 2 studies, $83 \%$ had hearing loss in mild to moderate category with an average ABG $33 \mathrm{~dB} .{ }^{1}$ In another study, it was $33 \mathrm{Db}$ and $46 \mathrm{Db}$ for specifications for posterior and anterior involvement of quadrant.

\section{Hearing improvement}

Two studies included patients without ossicular erosion were categorized into Austin-Kartush group 0. AustinKartush classification group A had 3 studies included. The mean ABG for each were $11.5 \mathrm{~dB}$ in first study, $8.3 \mathrm{~dB}$ second study and $13.5 \mathrm{~dB}$ for third study. Similarly, in group B, 3 studies were included. The mean ABG for each were $11.9 \mathrm{~dB}, 10.9 \mathrm{~dB}$ and $11.1 \mathrm{~dB}$. Group $\mathrm{C}$ had 4 studies. The mean ABG were $17.7 \mathrm{~dB}, 15 \mathrm{~dB}, 17.1 \mathrm{~dB}$ and $15.7 \mathrm{~dB}$. Group D had 4 studies included which had the same mean ABG $16.6 \mathrm{~dB}$. Group E had just 1 study of mean ABG $20.1 \mathrm{~dB}$.

\section{DISCUSSION}

Patients whose post-op ABG was less than $20 \mathrm{db}$ had good success rate in their surgery. The average ABG when comparing all the studies were $30 \mathrm{~dB} \cdot{ }^{6-12}$ Age factor did play a role, younger age group had better tolerance to surgery and outcomes as compared to older age groups. ${ }^{13-}$ 16

\section{CONCLUSION}

This review was an effort to standardise the degree of hearing improvement following tympanoplasty in Mucosal type of CSOM. For any degree of hearing loss, a better way to segregate the improvement rate of hearing gives a better picture to the patient as well as the surgeon. It improves the quality and standard of health care. Surgeon point of view, it helps for better treatment planning.

\section{Funding: No funding sources \\ Conflict of interest: None declared \\ Ethical approval: Not required}

\section{REFERENCES}

1. Blom EF, Gunning MN, Kleinrensink NJ, Lokin AS, Bruijnzeel $\mathrm{H}$, Smit $\mathrm{AL}$, et al. Influence of ossicular chain damage on hearing after chronic otitis media and cholesteatoma surgery: a systematic review and meta-analysis. JAMA OtolaryngologyHead and Neck Surg. 2015;141(11):974-82.

2. Lerut B, Pfammatter A, Moons J, Linder $\mathrm{T}$. Functional correlations of tympanic membrane perforation size. Otol Neurotol. 2012;33(3):379-86.

3. Miyamoto RT. Otitis media (chronic). Merck Manual website. http://www.merckmanuals.com /professional/ear-nose-and-throat-disorders /middleear-and-tympanic-membrane-disorders/otitis-mediachronic?qt=chronic $\% 20$ otitis $\% 20$ media\&alt=sh. Updated 2013. Accessed 14 November 2014.

4. Heyning VP, Mulder JS. 4 Aandoeningen van het trommelvlies en het middenoor. In Keelneusoorheelkunde en hoofd-halschirurgie 2007 (6178). Bohn Stafleu van Loghum, Houten.

5. Jeng FC, Tsai MH, Brown CJ. Relationship of preoperative findings and ossicular discontinuity in chronic otitis media. Otol Neurotol. 2003;24(1):2932.

6. Kurihara A, Yuasa R, Toshima M, Takasaka T. Bone destruction mechanisms in chronic otitis media with cholesteatoma: specific production by cholesteatoma tissue in culture of bone-resorbing activity attributable to interleukin-1 alpha. Ann Otol Rhinol Laryngol. 1991;100(12):989-98.

7. Austin DF. Ossicular reconstruction. Arch Otolaryngol. 1971;94(6):525-35.

8. Chole RA, McGinn MD, Tinling SP. Pressureinduced bone resorption in the middle ear. Ann Otol Rhinol Laryngol. 1985;94(2):165-70.

9. Yetiser S, Satar B, Aydin N. Expression of epidermal growth factor, tumor necrosis factor- $\alpha$, and interleukin- $1 \alpha$ in chronic otitis media with or without cholesteatoma. Otol Neurotol. 2002;23(5):647-52.

10. Huizing EH, Snow GB, Graamans K, editors. Keelneus - oorheelkunde en hoofd - halschirurgie. Bohn Stafleu van Loghum; 2007.

11. Patil DU, Burse KS, Kulkarni SV, Sancheti V, Bharadwaj C. Correlation of the pure tone audiometry findings with intraoperative findings in patients with chronic suppurative otitis media. MVP J Med Sci. 2015;2(1):4-14. 
12. Srinivas C, Kulkarni NH, Bhardwaj NS, Kottaram PJ, Kumar SH, Mahesh V. Factors influencing ossicular status in mucosal chronic otitis media: An observational study. Indian J Otolo. 2014;20(1):16.

13. Shariff ME. Analysis of hearing loss by pure tone audiometry in patients with chronic suppurative otitis media. National J of Physiology, Pharmacy and Pharmacology. 2019;9(6):515-8.

14. Varshney S, Nangia A, Bist SS, Singh RK, Gupta $\mathrm{N}$, Bhagat S. Ossicular chain status in chronic suppurative otitis media in adults. Indian $\mathbf{J}$ Otolaryngol Head Neck Surg. 2010;62(4):421-6.

15. Vartiainen E. Ten-year results of canal wall down mastoidectomy for acquired cholesteatoma. Auris Nasus Larynx. 2000;27(3):227-9.
16. Dornhoffer JL, Gardner E. Prognostic factors in ossiculoplasty: a statistical staging system. Otol Neurotol. 2001;22(3):299-304.

Cite this article as: Das D, Sriraman G, Rajasekaran $\mathrm{V}$. Establishment of significant improvement of hearing post-surgery for mucosal type of chronic suppurative otitis media. Int J Otorhinolaryngol Head Neck Surg 2020;6:1016-8. 